\title{
Preface
}

\section{Biodiversity, conservation and sustainable management of soil animals: the XV International Colloquium on Soil Zoology and XII International Colloquium on Apterygota}

\author{
George Gardner Brown ${ }^{(1)}$ and Klaus Dieter Sautter ${ }^{(2)}$
}

(1)Embrapa Florestas, Caixa Postal 319, CEP 83411-000 Colombo, PR, Brazil. E-mail: (2)Universidade Positivo, Rua Prof. Pedro Viriato Parigot de Sousa, no 5.300, Campo Comprido, CEP 81280-330 Curitiba, PR, Brazil. E-mail: ksautter@up.edu.br

\section{Introduction}

Much beyond being only substrates for growing plants, soils are living entities and the home of numerous organisms whose diversity may even surpass that of the aboveground flora and fauna. Soils are among the most biologically rich habitats on earth; nowhere in nature are species so densely packed as they are in soil communities (Hågvar, 1998). For example, a single gram of soil may contain millions of bacteria and several thousand species of microorganisms (Torsvik et al., 1996), while soils of tropical forest habitats (e.g., Amazonian or Atlantic Rainforests) may harbor more than 2,200 species of soil invertebrates in a single site (Mathieu, 2004). Of these, the vast majority is likely to be nematodes and insects, each representing more than 100 species. In fact, over 1 million species of insects may inhabit Brazilian ecosystems (Lewinsohn et al., 2005 ), and a large proportion of these, up to $25 \%$ or more using estimate of Decaëns et al. (2006a), may be associated with soils for an important part of their life cycle. More than 50,000 species of soil+litter inhabiting animals have been described from Brazil, being the beetles, Protozoa, spiders, nematodes, ants, and mites the most diverse, each with more than 1,000 classified or estimated species (Brown et al., 2006). However, most groups of soil animals remain poorly known, and their species diversity is certainly much larger than the currently known totals. Further efforts are urgently needed to overcome the taxonomic challenges involved in describing the world's soil biota, especially considering the potential negative impacts on global biodiversity of climate and further land use changes worldwide.

Soil animals perform various ecosystem services and key functions in both natural and agricultural ecosystems (Lavelle et al., 2006). Many soil fauna orders include predators active in biological control of pests and diseases; a large variety of detritivores and fungivores contribute significantly to decomposition of organic matter and nutrient cycling. Soil formation and physical properties are affected by bioturbating animals. Some soil fauna (e.g., snails, earthworms, ants, termites, beetle grubs, caterpillars) are important sources of food for indigenous human societies (Paoletti, 2005). Many insects that often spend a critical stage of their life cycle within the soil or on its immediate surface are important plant pollinators (Bater, 1996). The activity of soil animals can also significantly influence plant growth, both positively and negatively (pests). Finally, soil animals and their biodiversity have also been widely used as bioindicators of soil quality (Paoletti, 1999). In fact, the value of the ecosystem services, provided each year by the soil biota worldwide, might exceed US \$1.5 trillion (Pimentel et al., 1997).

To classify the vast biodiversity of soil fauna, understand their functional significance to soils, and quantify their financial impacts on human beings under rapidly changing socioenvironmental conditions, soil zoologists face major challenges. Recent advances in soil ecological theory, multivariate statistics and field and laboratory equipment and techniques have greatly aided soil zoologists in this process, but much of the work still involves many hours of careful observation in the field and under the microscope in the laboratory. We are still a long way from a comprehensive understanding of the biodiversity and function of soil fauna communities, particularly in the tropics, where land use changes and agricultural intensification have greatly impacted the soil, putting both biodiversity and functions at risk.

Scientific meetings, such as the International Colloquia on Soil Zoology and Apterygota, provide 
unique fora to discuss present advances and future perspectives of research in the field. Furthermore, the publications derived from these colloquia generally represent the "state of the art" of the science in the field, and often include seminal works that are "citation classics". Finally, these publications are a historical record of the development of the field of Soil Zoology, and should be considered obligatory reading for those initiating in the field.

In the present editorial, we briefly address the historical evolution of the colloquia and their derived publications and highlight the main results of the XV International Colloquium on Soil Zoology and of the XII International Colloquium on Apterygota, held in Curitiba, Brazil, in August-september, 2008.

\section{The Soil Zoology Colloquia}

In 1955, a one-week course at the University of Nottingham, entitled "Second Easter School in Agricultural Science", led to the publication of a book on soil zoology (Easter School in Agricultural Science, 1956). The undertaking of this colloquium may be considered a catalyst for the consolidation of Soil
Zoology as a discipline on its own (Kevan, 1985). In fact, this could (and probably should) be considered the first of the Colloquia on Soil Zoology which have been held regularly since then (Kevan, 1985). Nevertheless, it was not until the following year, at the $6^{\text {th }}$ International Society of Soil Science (ISSS) meeting in Paris, that the Soil Biology Commission of the ISSS instituted the Soil Zoology Committee, with the task of organizing a series of colloquia at regular intervals. Therefore, the first (or rather second) of these symposia took place at Rothamsted, in 1958, and was dedicated to Methods of Research in Soil Zoology (Murphy, 1962). A few years later, the Soil Zoology Committee became the Subcommission D of Commission III (Soil Biology) of the ISSS, with the responsibility of publishing at regular intervals the Bulletin of the Zoological Committee of the International Society of Soil Science, entitled "Biologie du Sol", starting in 1964, which in 1976 became "Pedofauna".

Since the colloquium at Rothamsted in 1958, the Soil Zoology colloquia have been held in various countries (Table 1), at approximately 3-4 year intervals (from 1970-1988 the colloquia were held every 3 years). Up until the 1988 colloquium ICSZ X (Veeresh et al.,

Table 1. Year, location, and publication of the past International Colloquia on Soil Zoology (ICSZ) and Apterygota (ICA).

\begin{tabular}{|c|c|c|c|}
\hline Colloquia & Year & Location & Publication \\
\hline \multicolumn{4}{|l|}{ Soil Zoology } \\
\hline ICSZ 0 & 1955 & Notingham, U.K. & Kevan (1956) \\
\hline ICSZ I & 1958 & Hertfordshire, U.K. & Murphy (1962) \\
\hline ICSZ II & 1962 & Oosterbeek, Netherlands & Doeksen \& van der Drift (1963) \\
\hline ICSZ III & 1966 & Braunschweig-Völkenrode, Germany & Graff \& Satchell (1967) \\
\hline ICSZ IV & 1970 & Dijon, France & d'Aguilar et al. (1971) \\
\hline ICSZ V & 1973 & Prague, Czekoslovack Republic & Vanek (1975) \\
\hline ICSZ VI & 1976 & Uppsala, Sweden & Lohm \& Persson (1977) \\
\hline ICSZ VII & 1979 & Syracuse, New York & Dindal et al. (1980) \\
\hline ICSZ VIII & 1982 & Louvain-la-Neuve, Belgium & Lebrun et al. (1983) \\
\hline ICSZ IX & 1985 & Moscow, Russia & Striganova (1987) \\
\hline ICSZ X & 1988 & Bangalore, India & Veeresh et al. (1991) \\
\hline ICSZ XI & 1992 & Jyväskylä, Finland & Haimi \& Huhta (1995) \\
\hline ICSZ XII & 1996 & Dublin, Ireland & Curry et al. (1998) \\
\hline ICSZ XIII & 2000 & České Budějovice, Čzeck Republic & Rusek (2002) \\
\hline ICSZ IVX & 2004 & Rouen, France & Decaëns et al. (2006) \\
\hline ICSZ XV & 2008 & Curitiba, Brazil & Brown \& Sautter (2009) \\
\hline \multicolumn{4}{|l|}{ Apterygota } \\
\hline ICA I & 1970 & Paris, France & \\
\hline ICA II & 1973 & Jevany, Czeckoslovack Republic & \\
\hline ICA III & 1976 & Södertälje, Sweden & \\
\hline ICA IV & 1979 & Krakow, Poland & \\
\hline ICA V & 1982 & Louvain-La-Neuve, Belgium & Gregoire-Wibo et al. (1983) \\
\hline ICA VI & 1985 & Moscow, Russia & Striganova (1987) \\
\hline ICA VII & 1988 & Bangalore, India & Veeresh et al. (1991) \\
\hline ICA VIII & 1992 & Helsinki, Finland & Vilkamaa (1994) \\
\hline ICA IX & 1996 & Dublin, Ireland & Bolger (1997) \\
\hline ICA X & 2000 & České Budějovice, Čzeck Republic & Rusek (2002) \\
\hline ICA XI & 2004 & Rouen, France & Thibaud et al. (2006) \\
\hline ICA XII & 2008 & Curitiba, Brazil & Brown \& Sautter (2009) \\
\hline
\end{tabular}


1991), all proceedings were published as books, many of which can be considered classic publications on Soil Zoology (Table 1). Each of these books contains a large number of papers that synthesize results of research being performed at the time, often including classical and well-cited reviews. Since 1992, starting with ICSZ XI in Jyväskylä, Finland, the proceedings have been published in peer-reviewed journals (Table 1): Acta Zoologica Fennica - ICSZ XI (Haimi \& Huhta, 1995), European Journal of Soil Biology - ICSZ XII and ICSZ XIV (Curry et al., 1998; Decaëns et al., 2006b), Applied Soil Ecology - ICSZ XIII (Rusek, 2001-2002), and Pesquisa Agropecuária Brasileira - ICSZ XV (Brown \& Sauter, 2009) (Table 1). These publications form the basis of much of our present knowledge on Soil Zoology.

The Soil Zoology Committee maintained close ties to the ISSS for many years, organizing special symposia at several ISSS meetings, held every four years. Nevertheless, a restructuring of the ISSS, after the $16^{\text {th }}$ ISSS meeting in Montpellier (1998), led to the disbanding of the Committee by the Soil Biology Commission (effective at the Bangkok meeting in 2002). Nonetheless, the chair and members of the Soil Zoology Committee decided to maintain the regularity of the colloquia, despite breaking of formal ties to the ISSS.

Up to the present date, 15 (or rather 16) ICSZ have been held, generally in Europe (13 out of the 16; Table 1), due to the traditionally large number of European participants and the long history of research on Soil Zoology in the member countries. The number of presentations at each colloquium has increased progressively with time, as also the number of participants (Figure 1). This reached its height at ICSZ XIV, where 356 participants contributed more

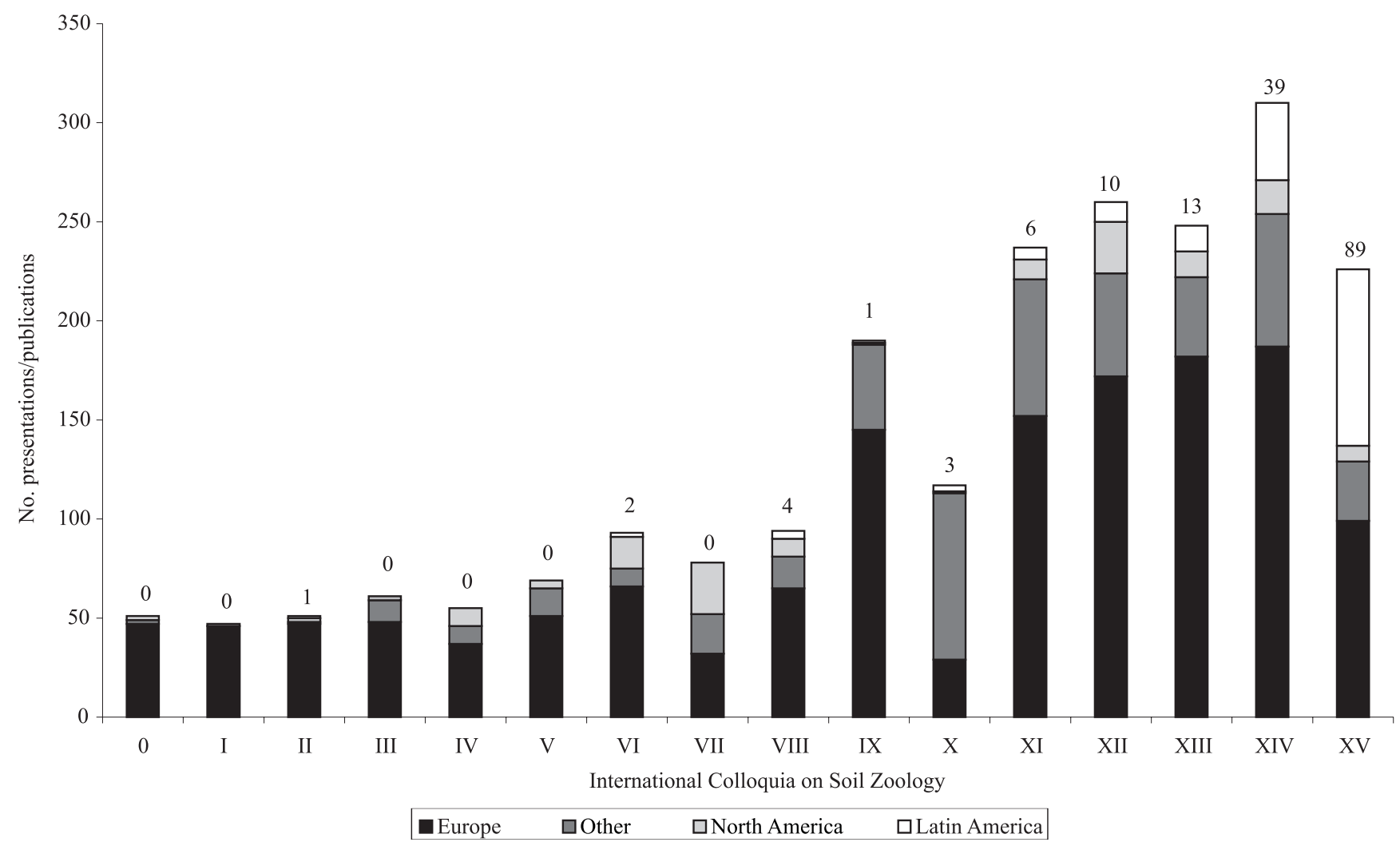

Figure 1. Total number of presentations (taken from the book of abstracts from 1992-2008) or papers published (taken from the colloquium proceedings, see Table 1) by representatives of different continents, at the International Colloquia on Soil Zoology. The number of presentations from Latin America is indicated at the top of the bars.Other includes Africa, Asia, Oceania and Antarctica. North America (Canada + USA), excluding Mexico. If the work was done by someone from any of these continents in another location, i.e., Siberia, East of Urals, Antarctica, or in Latin America or Africa (e.g., by a European, for instance), then it was counted as a contribution from the continent where the work was done (i.e., Latin America or Other if done in Asia, Antarctica, Oceania, Africa, etc.) 
than 300 presentations (oral + posters) (Decaëns et al., 2006b).

Oral and poster presentations and their resulting publications have been typically dominated by Europeans at most colloquia (Figure 1). However, when the colloquia have been held in other countries, especially India (ICSZ X) and Brazil (ICSZ XV), a large number of contributions were made by local scientists. These were the only two occasions when the proportion of contributions from Europe was under $50 \%$. Clearly, the realization of colloquia in other countries, outside Europe, provides unique opportunities to both strengthen local Soil Zoology chapters/societies, and share their research with scientists from other countries and continents. Both India and Russia have strong soil ecology/zoology societies that frequently organize meetings (Uvarov, 2001).

The traditionally low number of contributions by scientists from North America (the numbers in Figure 1 are for Canada and USA only, excluding Mexico), may be due, in part, to a later start in the development of research on Soil Zoology in the continent (Kevan, 1985). A progressive increase in presentations in recent colloquia was expected, considering the large and growing number of students and institutions involved in soil zoological research in Canada and the USA. Nevertheless, only in ICSZ VIII (International Colloquium on Soil Zoology, 1983) and ICSZ XII (Curry et al., 1998), did they surpass 20 presentations. However, this may be partly due to the fact that since 1985 they have a forum to present their own papers: the biennial meetings of the Soil Ecology Society.

\section{The XV International Colloquium on Soil Zoology}

The XV International Colloquium on Soil Zoology was held in Curitiba, Brazil, from 25 to 29 August, 2008. The colloquium was attended by approximately 160 participants from 25 countries: of these, $46 \%$ were from Latin America (83\% of these from Brazil), and $41 \%$ from Europe. This was the first time that the colloquium was held in the Southern Hemisphere and in Latin America (Table 1).

A total of 226 presentations were made, with 60 oral and 166 poster presentations. A special, one-day session covered the topic of Soil Zoology in the Tropics, with 63 presentations, 41 of them by Brazilian scientists and students. In fact, students were an important proportion of the participants, representing about one third of the total. Holding the colloquium in Brazil presented a unique opportunity for Latin American scientists to share with the rest of the world their research, a phenomenon which had been, up until then, very limited. At the ICSZ XV (Brown \& Sautter, 2009), 89 presentations were by Latin American scientists/ students. Although the number of presentations of Latin American scientists had been increasing, particularly in the last three colloquia (Figure 1), historically, the colloquia have been poorly attended by delegates from Latin America and other developing countries, mainly due to the high cost of participation.

Considering the country of the colloquium (Brazil) is one of the world's largest producers of agricultural products (Alexandratos, 1995), and the venue (Curitiba) is located in the Atlantic Rainforest, one of the world's hot-spots of biodiversity (Mittermeier et al., 2005), and home to a large number of endemic, endangered species (Machado et al., 2005), we felt it appropriate to select the main theme of the colloquium as "Biodiversity, Conservation and Sustainable Management of Soil Animals".

The colloquium was thus organized around 4 main sessions that addressed eight themes. Session 1, "Soil Animal Biodiversity: The Final Frontier", addressed the themes of "Monitoring Soil Animal Biodiversity" and "Soil Animals as Environmental Bioindicators". This session was one of the most popular, with 60 presentations, most of them covering the first theme (biodiversity). Session 2, "Soil Animals as Pests and Beneficials in Sustainable Land Use Systems", addressed the themes of "Soil Animals as Pests and Beneficials" and "Soil Animal Ecology and Ecotoxicology". Session 3, "Soil Zoology in the Tropics", covered the developments in soil zoology in general in the Neotropics and the Paleotropics, with the vast majority of the presentations $(87 \%)$ devoted to results of neotropical studies (Latin America). The final session, "Soil Animals and Ecosystem Services", addressed the themes "Soil Animals and Ecosystem Sustainability" and "Global Ecosystem Changes and Soil Animals", with most (40 out of 48) presentations devoted to the first theme.

Combining the topics presented in session 3 within the others of the remaining sessions, it became obvious that most of the presentations addressed a topic of still

Pesq. agropec. bras., Brasília, v.44, n.8, p. i-ix, ago. 2009 
much apparent need for research, particularly in the Tropics: biodiversity assessments (Figure 2). In this theme, as in others, most of the work presented was by Europeans. Taxonomic impediments continue to be a great hindrance for this type of research in the Tropics, and much of the work is still performed by and in partnership with European scientists and institutions [e.g., Solobioma project; see papers of Römbke et al. (2009) and Schmelz et al. (2009)]. It is hoped that with time and more emphasis placed on training of national scientists, in different tropical countries, dependence on European specialists for taxonomic work will decrease, facilitating the work for future generations of developing countries' scientists.

The effects of global change on soil animals, another topic of preeminent research, still continues to be greatly overlooked and little understood, and the number of presentations on the topic was greatly limited.

The publication of this issue of Pesquisa Agropecuária Brasileira includes 39 papers; 31 are from ICSZ XV (Brown \& Sauter, 2009) and 9 from ICA XII (Brown \& Sauter, 2009) (see below). Of former papers, four are general reviews on the importance of soil fauna (Anderson, 2009),

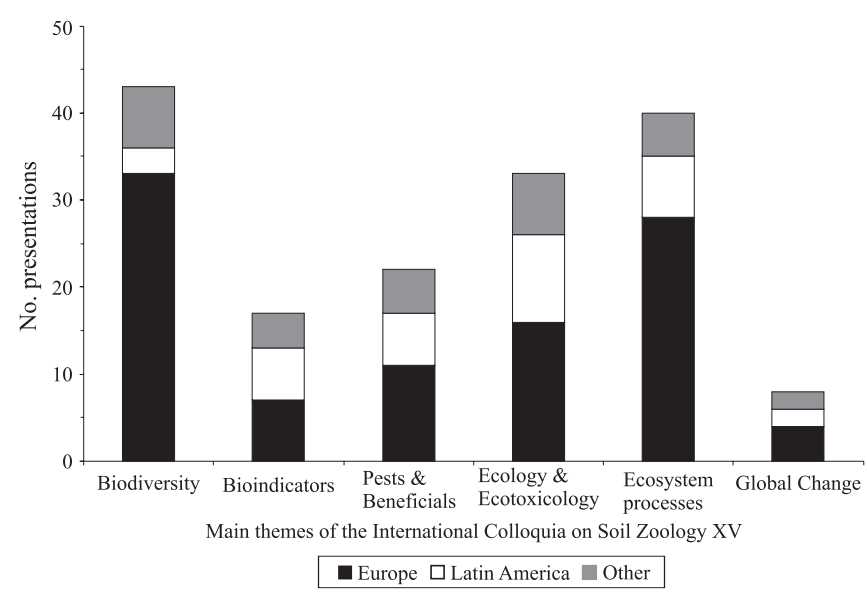

Figure 2. Number of presentations made on the main themes of the XV International Colloquium on Soil Zoology, by representatives of different continents. Other continents include Asia, Oceania, North America (excluding Mexico), and Africa. ecotoxicology (Kuperman et al., 2009), the role of soil zoology in ecological theory (Lavelle, 2009), and sampling methods for soil biota (Bignell, 2009). Most of the papers in this special issue are ecologically-based studies that address basic aspects of soil animals (biodiversity, abundance), in various ecosystems, and the impact of management practices on soil fauna. Several of these approach the use of various members of the soil fauna (e.g., nematodes, earthworms, ants) or their communities (especially the macrofauna) as bioindicators. Interestingly, very few papers dealt with the basic biology of soil animals (Grigoropoulou et al., 2009), although there is still much to be discovered of the behavior of many species and groups of soil invertebrates. Three papers address rather specific methodological (Souza et al., 2009) for ants and ecotoxicological (Piola et al., 2009; Pižl et al., 2009) issues of soil fauna. Two additional papers address the pros and cons of relatively new techniques in Soil Zoology: DNA barcoding (Rougerie et al., 2009) and earthworm marking using visual implants (Butt et al., 2009).

Other developments at ICSZ XV (Brown \& Sauter, 2009) were the selection and election of a new chair and of members of the Soil Zoology Committee (see list at the end of this editorial). It was agreed that the chairman always be the organizer of the last colloquium, and that the previous organizer be also part of the committee. Furthermore, it was proposed that the membership include a wide geographic spread, with representatives from each continent (except Antarctica). It was also decided that a proposal be sent to the IUSS for a special symposium at the upcoming $19^{\text {th }}$ meeting in Brisbane, Australia. The proposal was sent and approved, and a special session on soil ecosystem services of soil fauna will take place at the conference. Furthermore, the following venue and organizer of the next colloquium were chosen: ICSZ XVI will take place in Coimbra, Portugal, organized by Dr. José Paulo Sousa.

\section{Apterygota Colloquia}

The first Apterygota colloquium was held in Paris in 1970. Since then, the colloquia have been held every 3-4 years (since 1988, they have been held every 4 years), generally in European countries (Table 1). Only twice have they been held outside Europe: in Bangalore, India, 1988 (Veeresh et al., 1991), and 
twenty years later in Curitiba, Brazil, 2008 (Brown $\&$ Sauter, 2009). The proceedings of the colloquia have been published mainly in Pedobiologia as well as in several books (Table 1). Unfortunately, we could not find a record of the publication of the first four colloquia, even when consulting some of the experts in the field (e.g., José G. Palácios-Vargas, Jean-Marc. Thibaud, Franz Janssens). Therefore, we could not offer an estimate of the contribution of scientists from different continents to research on Apterygota at the last 12 colloquia, as was done for the Soil Zoology colloquia (we hope that this task can be undertaken by future colloquia organizers). Nevertheless, it is well known that several taxonomists and ecologists are and have been actively studying Apterygota throughout the world, several of them in Latin America, although their contributions to the Apterygota colloquia have generally been limited.

The XII International Colloquium on Aptyerygota was held in Curitiba, Brazil, September 1-2, 2008 (Brown \& Sauter, 2009). The colloquium was divided in two sessions: (1) "Ecology, Bioindication and Conservation", which included two themes - "The role of Apterygota in Restoration and Conservation" and "Behaviour in Apterygota"; and (2) Morphology, Anatomy and Ultrastructure.

The undertaking of the XII Colloquium in Curitiba was a unique opportunity to bring together Apterygota researchers from Latin America, and especially Brazil (this was the first meeting of Brazilian specialists). The Colloquium had 25 participants, 18 from Latin America (72\%), most from Brazil (12). Delegates from Germany, Poland, Spain, USA, Japan and China were also present. In a total of 20, oral (7) and poster (13) presentations were made. Of these, 2 oral and 8 poster presentations were by Brazilians, representing $50 \%$ of the total. Altogether Latin American scientists were responsible for $60 \%$ of all contributions. In fact, the Colloquium initiated a new era for Apterygota research in Brazil: the meeting prompted the organization of the I Brazilian Workshop on Collembola Taxonomy, to be held in September 2009, in João Pessoa, Brazil, bringing together all Brazilian Collembola researchers.

Of the 39 papers in the present thematic issue, nine were derived from ICA XII (Brown \& Sauter, 2009). These are mainly descriptive in nature, focusing on the presence of particular species or communities of Apterygota in different ecosystems, including the impacts of flooding (Marx et al., 2009; Wild et al., 2009) and environmental pollution (Fiera et al., 2009) on Collembola. Finally, two papers deal mainly with morphological characteristics of Collembola (Palácios-Vargas \& Meneses, 2009) and Archaeognatha (Bach).

\section{Future perspectives}

Tropical countries such as Brazil are host to a large part of the world's biodiversity, much of it living in the soil (Lewinsohn et al., 2005; Brown et al., 2006). However, many species of the soil biota must still be discovered and described, and this is limited by the few specialists working in the region. Mainstreaming and facilitation of taxonomy, as well as training and research on the biology and life history of many groups and species of soil fauna must be prioritized, if we are to reach an adequate understanding of soil biodiversity and its role in natural and agricultural ecosystems in the tropics.

Soil animals are part of the biological resources that need to be managed in productive ecosystems (Lavelle et al., 2001). They contribute important ecosystem services (Lavelle et al., 2006), can be used as indicators of the health of the system and play an important part in maintaining its fertility and productivity (Paoletti, 1999). A diverse community of soil animals may help reduce pest outbreaks (Lavelle et al., 2004), and their activity creates and maintains soil structure (McGill \& Spence, 1985), regulates decomposition and mineralization processes and can influence the long-term turnover and protection of organic matter (Lavelle et al., 2001). Therefore, proper and sustainable management practices, in particular those that preserve and enhance the litter layer (quality and quantity), protect the soil's physical integrity, minimize the use of external synthetic inputs (especially pesticides), and enhance soil organic resources will be the most interesting to promote soil animal activities and their beneficial role in soils (Lavelle et al., 2003).

The organization of international colloquia, such as these held in Brazil, are unique opportunities to bring together experts in the field and share results of the latest and most up-to-date research in the growing field of Soil Zoology. The papers here presented address many of the above topics, and we believe that this issue of Pesquisa Agropecuária Brasileira constitutes an important contribution to the main and subsidiary 
themes of the colloquium. However, we acknowledge that there is still much to be done to adequately identify, preserve and manage soil animals, and these topics will certainly still provide many challenges to researchers in the future, especially in tropical countries.

\section{Acknowledgements}

The colloquium received financial support from the following agencies/institutions: Technical Centre for Agricultural and Rural Cooperation (CTA), European Union, Conselho Nacional de Desenvolvimento Científico e Tecnológico, Fundação de Pesquisas Florestais do Paraná, Conselho Regional de Engenharia Arquitetura e Agronomia do Paraná, Fundação Araucária, Petróleo Brasileiro S.A. (Petrobrás), Coordenação de Aperfeiçoamento de Pessoal de Nível Superior, Institut de Recherche pour le Développement, Empresa Brasileira de Pesquisa Agropecuária (Embrapa), and Governo do Paraná. The authors acknowledge the support of the organizing institutions, students and colleagues from: Embrapa Florestas, Universidade Positivo, Universidade Estadual de Londrina and Universidade Federal do Paraná. Mac Callaham, Greta Langhenry, Andrey Zaytsev and Patrick Lavelle graciously provided information to complete Figure 1. Jean-Marc Thibaud provided information for Table 1. Patrick Lavelle and Clive Edwards provided useful comments. Finally, we thank the hard work of the technical editors (Geoff Baker, David Bignell, Juvenil Cares, Elizabeth Franklin-Chilson, Thibaud Decaëns, Marcos Garcia, Hubert Höfer, Nobuhiro Kaneko, Patrick Lavelle, Flávio Luizão, Renato Marques, Jörg Römbke, José Paulo Sousa, Douglas Zeppelini), without whose help and contributions this thematic issue would not have been possible.

In addition, we would like to thank the support from Embrapa Informação Tecnológica and the Pesquisa Agropecuária Brasileira journal staff, for editing this thematic issue.

\section{References}

ALEXANDRATOS, N. World agriculture: towards 2010. New York: John Wiley \& Sons, 1995.

ANDERSON, J.M. Why should we care about soil fauna? Pesquisa Agropecuária Brasileira, v.44, p.835-842, 2009.
BATER, J.E. Micro- and macro-arthropods. In: HALL, G.S. (Ed.). Methods for the examination of organismal diversity in soils and sediments. Wallingford: CAB International, 1996. p.163-174.

BIGNELL, D.E. Towards a universal sampling protocol for soil biotas in the humid tropics. Pesquisa Agropecuária Brasileira, v.44, p.825-834, 2009.

BOLGER, T. (Ed.). Proceedings of the IX International Colloquium on Apterygota, Dublin, 1996. Pedobiologia, v.41, n.1-3, 1997.

BROWN, G.G.; RÖMBKE, J.; HOFER, H.; VERHAAG, M.; SAUTTER, K.D.; SANTANA, D.L.Q. Biodiversity and function of soil animals in Brazilian agroforestry systems. In: GAMA-RODRIGUES, A.C.; BARROS, N.F.; GAMA-RODRIGUES, E.F.; FREITAS, M.S.; VIANA, A.P.; JASMIN, J.M.; MARCIANO, C.R.; CARNEIRO, J.G.A. (Ed.). Sistemas agroflorestais: bases cientícias para o desenvolvimento sustentado. Campos dos Goytacazes: UENF, 2006. p.217-242.

BROWN, G.G.; SAUTTER, K.D. (Ed.). Biodiversity, conservation and sustainable management of soil animals: the XV International Colloquium on Soil Zoology and XII International Colloquium on Apterygota. Pesquisa Agropecuária Brasileira, v.44, p.789-1071, 2009.

BUTT, K.R.; BRIONES, M.J.I.; LOWE. C.N. Is tagging with visual implant elastomer a reliable technique for marking earthworms? Pesquisa Agropecuária Brasileira, v.44, p.969-974, 2009.

COLLOQUIUM ON DYNAMICS OF SOIL COMMUNITIES, 1966, Braunschweig Völkenrode. Progress in soil biology: proceedings. Amsterdam: North Holland Publishing Company, 1967. Editors: Otto Graff; John E. Satchell.

COLLOQUIUM ON SOIL FAUNA, SOIL MICROFLORA, AND THEIR RELATIONSHIPS, 1962, Amsterdam. Soil organisms: proceedings. Amsterdam: North Holland, 1963. Editors: J. Doeksen; J. Van Der Drift.

CURRY, J.P.; BOLGER, T.; PURVIS, G. (Ed.). XII International Colloquium on Soil Zoology, Dublin, 1996. Applied Soil Ecology, v.9, p.1-542, 1998.

D'AGUILAR, C.A.H.J.; BESSARD, A.; BOUCHÉ, M.B.; PUSSARD, M. Organismes du sol et production primaire. In: COLLOQUIUM OF THE ZOOLOGY COMMITTEE OF THE INTERNATIONAL SOCIETY OF SOIL SCIENCES, 4., 1970, Dijon. Proceedings. Versailles: INRA Publications, 1971. p.71-77.

DECÄENS, T.; JIMÉNEZ, J.J.; GIOIA, C.; MEASEY, G.J.; LAVELLE P. The values of soil animals for conservation biology. European Journal of Soil Biology, v.42, p.23-38, 2006a. Supplement.

DECÄENS, T.; LAVELlE P.; AUBERT, M.; BAROT, S.; BUREAU, F.; MARGERIE, P.; MORA, P.; ROSSI, J.P. (Ed.). Soil animals and ecosystems services. Proceedings of the XIV International Colloquium on Soil Zoology. European Journal of Soil Biology, v.42, p.1-366, 2006b. Supplement.

EASTER SCHOOL IN AGRICULTURAL SCIENCE, 2., 1955, Nottingham. Soil zoology: proceedings. New York: Academic, 1956. Editor: D. Keith Mc.E. Kevan.

FIERA, C. Biodiversity of Collembola in urban soils and their use as bioindicators for pollution. Pesquisa Agropecuária Brasileira, v.44, p.868-873, 2009. 
GREGOIRE-WIBO, C.; LEBRUN, P.; TÖRNE, E. (Ed.). Comptes Rendus du V Colloque International sur les Aptérygotes, 1982, Louvain-La-Neuve. Pedobiologia, v.25, p.1-48, p.197-372, 1983.

GRIGOROPOULOU, N.; BUTT, K.R.; LOWE, C.N. Interactions of juvenile Lumbricus terrestris with adults and their burrow systems in a two-dimensional microcosm. Pesquisa Agropecuária Brasileira, v.44, p.964-968, 2009.

HÅGVAR, S. The relevance of the Rio-Convention on biodiversity to conserving the biodiversity of soils. Applied Soil Ecology, v.9, p.1-7, 1998 .

HAIMI, J.; HUHTA, V. (Ed.). Soil organisms and soil health. XI International Colloquium on Soil Zoology, 1992, Jyväskylä. Acta Zoologica Fennica, n.196, p.1-384, 1995.

INTERNATIONAL COLLOQUIUM ON SOIL ZOOLOGY, 7., 1979, Syracuse. Soil biology as related to land use practices: proceedings. Washington: Environmental Protection Agency, 1980. Editor: D.L. Dindal.

INTERNATIONAL COLLOQUIUM ON SOIL ZOOLOGY, 8., 1982, Louvain-la-Neuve. New trends in soil biology: proceedings. Louvain-la-Neuve: Dieu-Brichard, 1983. Editors: P. Lebrun; AM. André; A. Medts; C. Gregoire-Wibo; G. Wauthy.

INTERNATIONAL COLLOQUIUM ON SOIL ZOOLOGY, 9., 1985, Moscow. Nauka: Moscow, 1987. Soil fauna and soil fertility: proceedings. Moscow: Nauka, 1987. Editor: B.R. Striganova.

KEVAN, D.K.Mc.E. Soil zoology, then and now - mostly then. Quaestiones Entomologicae, v.21, p.371.7-472, 1985.

KUPERMAN, R.G.; CHECKAI, R.T.; GARCIA, M.G.; RÖMBKE, J.; STEPHENSON, G.L.; SOUSA, J.P. Ecotoxicological assessment of contaminated land: the state-of-art and the way forward. Pesquisa Agropecuária Brasileira, v.44, p.811-824, 2009.

LAVELLE, P. Ecology and the challenge of a multifunctional use of soil. Pesquisa Agropecuária Brasileira, v.44, p.803-810, 2009.

LAVELLE, P.; BARROS, E.; BLANCHART, E.; BROWN, G.G.; DESJARDINS, T.; MARIANI, L.; ROSSI, J.P. SOM Management in the tropics: why feeding the soil macrofauna? Nutrient Cycling in Agroecosystems, v.61, p.53-61, 2001.

LAVELLE, P.; BLOUIN, M.; BOYER, J.; CADET, P.; LAFFRAY, D.; PHAM-THI, A.T.; REVERSAT, G.; SETTLE, W.; ZUILY, Y. Plant parasite control and soil fauna diversity. Comptes Rendues Biologies, v.327, p.629-638, 2004.

LAVELLE, P.; DECAËNS, T.; AUBERT, M.; BAROT, S.; BLOUIN, M.; BUREAU, F.; MARGERIE, P.; MORA, P.; ROSSI, J.P. Soil invertebrates and ecosystem services. European Journal of Soil Biology, v.42, p.3-15, 2006. Supplement.

LAVELLE, P.; SENAPATI, B.K.; BARROS, E. Soil macrofauna. In: SCHROTH, G., SINCLAIR, F.L. (Ed.). Trees, crops and soil fertility: concepts and research methods. Wallingford: CAB International, 2003. p.303-323.

LEWINSOHN, T.M.; FREITAS, A.V.L.; PRADO, P.I. Conservation of terrestrial invertebrates and their habitats in Brazil. Conservation Biology, v.19, p.640-645, 2005.

LOHM, U.; PERSSON, T. (Ed.). Soil organisms as components of ecosystems. Proceedings of the VI International Soil Zoology Colloquium, Uppsala, 1976.Ecological Bulletins, v.25, p.1-614, 1977.
MACHADO, A.B.M.; MARTINS, C.S.; DRUMMOND, G.M. Lista da fauna brasileira ameaçada de extinção, incluindo as listas das espécies quase ameaçadas e deficientes em dados. Belo Horizonte: Fundação Biodiversitas, 2005.

MARX, M.T.; WILD, A.K.; KNOLLMANN, U.; KAMP, G.; WEGENER, G.; EISENBEIS, G. Responses and adaptations of collembolan communities (Hexapoda: Collembola) to fl ooding and hypoxic conditions. Pesquisa Agropecuária Brasileira, v.44, p.1002-1010, 2009.

MATHIEU, J. Étude de la macrofaune du sol dans une zone de déforestation en Amazonie du sud-est, dans le contexte de l'agriculture familiale. 2004. 238p. Thesis (PhD) - University of Paris VI, Paris.

MCGILL, W.B.; SPENCE, J.R. Soil fauna and soil structure: feedback between size and architecture. Quaestiones Entomologicae, v.21, p.645-654, 1985

MITTERMEIER, R.; GIL, P.R.; HOFFMAN, M.; PILGRIM, J.; BROOKS, T.; MITTERMEIR, C.G.; LAMOREUX, J.; DA FONSECA, G.A.B. Hotspots revisited: earth's biologically richest and most endangered terrestrial ecoregions. Monterrey: Cemex, 2005.

MURPHY, P.W. (Ed.). Progress in soil zoology. London: Butterworths, 1962. Papers from a Colloquium on Research Methods (in Soil Zoology).

PALÁCIOS-VARGAS, J.G.; MENESES, G.C. Importance and evolution of sexual dimorphism in different families of Collembola (Hexapoda). Pesquisa Agropecuária Brasileira, v. 44, p.959-963, 2009.

PAOLETTI, M.G. (Ed.). Ecological implications of minilivestock: potential of insects, rodents, frogs and snails. Enfield: Science Publishers, 2005. 648p.

PAOLETTI, M.G. (Ed.). Invertebrate biodiversity as bioindicators of sustainable landscapes: practical use of invertebrates to assess sustainable land use. Amsterdam: Elsevier, 1999. 444p. (Agriculture, Ecosystems \& Environment, v.74).

PIMENTEL, D.; WILSON, C.; MCCULLUM, C.; HUANG, R.; DWEN, P.; FLACK, J.; TRAN, Q.; SALTMAN T.; CLIFF, B. Economic and environmental benefits of biodiversity. BioScience, v.47, p.747-757, 1997.

PIOLA, L.; FUCHS, J.; OETO, M.L.; BASACK, S.; GIMÉNEZ, R.; MASSARO, R.; PAPA, J.C.; KESTEN, E.; CASABÉ, $\mathrm{N}$. Biomarkers for the assessment of chlorpyrifos effects on earthworms in an Argentine wheat field. Pesquisa Agropecuária Brasileira, v.44, p.874-880, 2009.

PIŽL, V.; SCHLAGHAMERSKÝ, J.; TŘÍSKA, J. The effects of polycyclic aromatic hydrocarbons and heavy metals on terrestrial annelids in urban soils. Pesquisa Agropecuária Brasileira, v.44, p.1050-1055, 2009.

RÖMBKE, J.; SCHMIDT, P.; HÖFER, H. The earthworm fauna of regenerating forests and anthropogenic habitats in the coastal region of Paraná. Pesquisa Agropecuária Brasileira, v.44, p.1040-1045, 2009.

ROUGERIE, R.; DECAËNS, T.; DEHARVENG, L.; PORCO, D.; JAMES, S.W.; CHANG, C.H.; RICHARD, B.; POTAPOV, M.; SUHARDJONO, Y.; HEBERT, P.D. N. DNA barcodes for soil animal taxonomy. Pesquisa Agropecuária Brasileira, v.44, p.789-802, 2009 . 
RUSEK, J. (Ed.). Biodiversity of soil organisms and ecosystem functioning. XIII International Colloquium on Soil Zoology, Ceske Budejovice, 2000. European Journal of Soil Biology, v.37-38, 2001-2002.

RUSEK, J. (Ed.). Proceedings of the Xth International Colloquium on Apterygota, České Budějovice 2000: Apterygota at the Beginning of the Third Millennium. Pedobiologia, v.46, p.198-413, 2002.

SCHMELZ, R.M.; COLLADO DE LA PEÑA, R.M.; RÖMBKE, J. Benefits from ecological study methods to taxonomy of enchytraeids in southern Mata Atlântica. Pesquisa Agropecuária Brasileira, v.44, p.861-867, 2009.

SOUZA, J.L.P. de; MOURA, C.A.R. de; FRANKLIN, E. Efficiency in inventories of ants in a Central Amazonia forest reserve. Pesquisa Agropecuária Brasileira, v.44, p.940-948, 2009.

THIBAUD, J.M.; DEHARVENG, L.; D'HAESE, C.; BETSCH, J.M. Proceedings of the XI International Colloquium on Apterygota, Rouen, France, 2004. Pedobiologia, v.50, p.81-206, 2006.
TORSVIK, V.; SØRHEIM, R.; GOKSØYR, J. Total bacterial diversity in soil and sediment communities - a review. Journal of Industrial Microbiology and Biotechnology, v.17, p.170-178, 1996.

UVAROV, A.V. $2^{\text {nd }}$ all-Russian conference on soil zoology. Pedobiologia, v.45, p.188-191, 2001.

VANEK, J. (Ed.). Progress in soil zoology. Proceedings of the V International Colloquium on Soil Zoology. Prague: Akademia, 1975.

VEERESH, G.K.; RAJAGOPAL, D.; VIRAKTAMATH, C.A. Advances in management and conservation of soil fauna. New Delhi: Oxford \& IBH, 1991. 925p.

VILKAMAA, P. Proceedings of the VIII International Colloquium on Apterygota, Helsinki, 1992. Acta Zoologica Fennica, n.195, p.1-156, 1994.

WILD, A.K.; MARX, M.T; EISENBEIS, G. A new method to simulate the hydrological state of soil under natural conditions. Pesquisa Agropecuária Brasileira, v.44, p.843-851, 2009.

\section{Members of the Soil Zoology Committee (2008-2012)}

\section{Chairman}

George Brown, Brazil

\section{Past Chairman}

Patrick Lavelle, France

\section{Members}

Adetola Badejo, Nigeria

Geoff Baker, Australia

Thibaud Decaëns, France

Mark Hassal, UK

Nobuhiro Kaneko, Japan

Roman Kuperman, USA

Anna Rozen, Poland

Gladys Stephenson, Canada

Andrey Zaitsev, Russia 